\title{
Comment on "Emplazamiento del magmatismo Paleoceno-Eoceno bajo un régimen transtensional y su evolución a un equilibrio dinámico en el borde occidental de Colombia" by Grajales et al., Rev. Mex. Cienc. Geol. (2020), 37(3), 250-268
}

\author{
Ángel A. Barbosa-Espitia ${ }^{1,3, *}$, George D. Kamenov ${ }^{1}$, David A. Foster ${ }^{1}$, \\ Sergio A. Restrepo-Moreno ${ }^{1,2}$, Andrés Pardo-Trujillo ${ }^{3}$, and Sebastián Echeverri ${ }^{3}$ \\ ${ }^{1}$ Department of Geological Sciences, University of Florida; 241 Williamson Hall, Gainesville, FL, 32611, USA. \\ ${ }^{2}$ Departamento de Geociencias y Medio Ambiente, Facultad de Minas, Universidad Nacional de Colombia, \\ Carrera 80 \# 65-223, Núcleo Robledo, Medellín, Colombia. \\ ${ }^{3}$ Departamento de Ciencias Geológicas, Instituto de Investigaciones en Estratigrafía (IIES), Universidad de Caldas, \\ Calle 65 \# 26-10, edificio Orlado Sierra, Bloque B, segundo piso, Manizales, Colombia. \\ *angelbarbosae@gmail.com, angelbarbosa@ufl.edu
}

\begin{abstract}
Grajales et al. (2020) reviewed geochronological and geochemical data from Paleogene volcanic and plutonic rocks outcropping in the Panama-Choco Block (north western Cordillera) and southern Western Cordillera, as well as the Central Cordillera of Colombia. These data were used to support a model of continuous Paleogene arc magmatism along the Colombian continental margin, and to propose a paleogeographic model for the arc. The authors did not discuss previously published paleomagnetic, geochemical, geochronological, thermochronological and provenance constraints from Cretaceous to Miocene rocks of western and northern Colombia, Panama, and Ecuador that support a more plausible model of a double subduction system controlled by the convergence of the Caribbean and Farallon plates beneath the north Andean block during Paleogene. In this comment, we discuss shortcomings in the data and model proposed by Grajales et al. (2020) and present an alternative interpretation for contemporaneous arc-like magmatism during the Paleogene in the Northern Andes. We conclude that the double subduction system is the more plausible explanation for the contemporaneous arc-like magmatism during the Paleogene, currently exposed in the northern and southern portions of the Northern Andes.
\end{abstract}

Key words: Northern Andes; circum-Caribbean paleogeography; arc magmatism; Panama-Choco Block; Paleogene tectonics.

\section{RESUMEN}

Grajales et al. (2020) hacen una revisión de la información geocronológica y geoquímica de rocas plutónicas y volcánicas aflorantes en el Bloque Panamá-Chocó (norte de la Cordillera Occidental), sur de la Cordillera Occidental, así como la Cordillera Central de Colombia. Estos datos fueron usados para plantear un modelo de un arco continental del Paleógeno continuo a lo largo del margen continental colombiano y para proponer un modelo paleogeográfico y de emplazamiento para las rocas ígneas del arco propuesto. Sin embargo, los autores no discutieron los datos geoquímicos, geocronológicos, termocronológicos y de proveniencia publicados para rocas cretácicas-miocénicas del noroccidente colombiano, Panamá y Ecuador, los cuales sugieren un modelo más probable de doble subducción controlado por la convergencia de las placas Caribe y Farallón bajo el Bloque Norandino durante el Paleógeno. En este comentario, se discuten algunos problemas relacionados con la compilación e interpretación de los datos y el modelo presentados por Grajales et al. (2020). Después de esta discusión llegamos a la conclusión que la presencia de un sistema de subducción doble es la explicación más razonable para el magmatismo de arco paleógeno, actualmente presente en los sectores sur $y$ norte de los Andes del Norte.

Palabras clave: Andes del Norte; Paleogeografía de la región circumCaribe; magmatismo de arco; Bloque Panamá-Chocó; tectónica del Paleógeno.

\section{INTRODUCTION}

Grajales et al. (2020) discussed geochronological and geochemical data from Paleogene arcs developed at three locations of the northwestern South America: Panama-Choco Block, which they called northern Western Cordillera (WC), southern WC, and Central Cordillera (CC), now juxtaposed onto the Colombian Andes (Figure 1). They reported geochemical data from the southern WC and geochronological data already published and discussed by BarbosaEspitia et al. (2019) (Figure 1). These data were combined with previously published geochemical and geochronological data, and interpreted to result from a single, continuous Paleogene arc along the paleocontinental margin of the Colombian Andes, which formed as a result of the subduction of the Farallon Plate in a transtensional tectonic setting. This paleogeographic and tectonic interpretation contrasts with well-established models for double subduction of the

Barbosa-Espitia, Á.A., Kamenov, G.D., Foster, D.A., Restrepo-Moreno, S.A., Pardo-Trujillo, A., Echeverri, S., 2021, Comment on “Emplazamiento del magmatismo Paleoceno-Eoceno bajo un régimen transtensional y su evolución a un equilibrio dinámico en el borde occidental de Colombia” by Grajales et al., Rev. Mex. Cienc. Geol. (2020), 37(3), 250-268: Revista Mexicana de Ciencias Geológicas, v. 38, núm. 2, p. 141-147. 
Farallon and Caribbean plates proposed for the origin of Paleogene arc-like rocks in Colombia, Ecuador and Panama (e.g., Cardona et al., 2018, Barbosa-Espitia et al., 2019; Vallejo et al., 2020). The doublesubduction hypothesis is based on a large and diverse data set including field work, paleomagnetic, geochronologic, geochemical and isotopic studies (e.g., Restrepo and Toussaint, 1990; Estrada, 1995; Chiaradia, 2009; Pindell and Kennan, 2009; Bayona et al., 2012; Montes et al., 2012; Boschman et al., 2014; Wright et al., 2016; Cardona et al., 2018; Barbosa-Espitia et al., 2019; Montes et al., 2019; Vallejo et al., 2019, 2020). We welcome discussions on the tectonic and paleogeographic evolution of the Northern Andes during the Paleogene to improve our understanding of this complex orogenic system involving interactions of several tectonic plates. However, the profound implications of the model proposed by Grajales et al. (2020) for ore deposits, hydrocarbon prospectivity, and geohazards, requires a careful examination of the presented data and interpretations.

\section{TEMPORAL AND GEOCHEMICAL CONSTRAITNS}

Grajales et al. (2020) compiled several whole rock geochemical data and Paleogene geochronological dates from magmatic rocks of the Panama-Choco Block, southern WC (Timbiquí Complex), and CC to establish a temporal and magmatic framework for their work (Grajales et al., 2020, table 4 and supl. mat.) (Figure 1). However, the authors made some mistakes when compiling the data. Grajales et al. (2020) presented geochronological data for the Antioquia, Ibagué, Sabanalarga and Buga batholiths with ages between $\sim 44$ and $59 \mathrm{Ma}$, which they consider crystallization ages obtained by the U/ $\mathrm{Pb}$ method (Grajales et al., 2020, table 4). However, after a revision of such data it is clear that Grajales et al. (2020) erroneously included ${ }^{40} \mathrm{Ar} /{ }^{39} \mathrm{Ar}$ ages, as well as zircon and apatite fission-track ages reported by Villagómez and Spikings (2013) and ANH- UCaldas (2011), as if they were $\mathrm{U} / \mathrm{Pb}$. These Ar/Ar and fission-track appar-

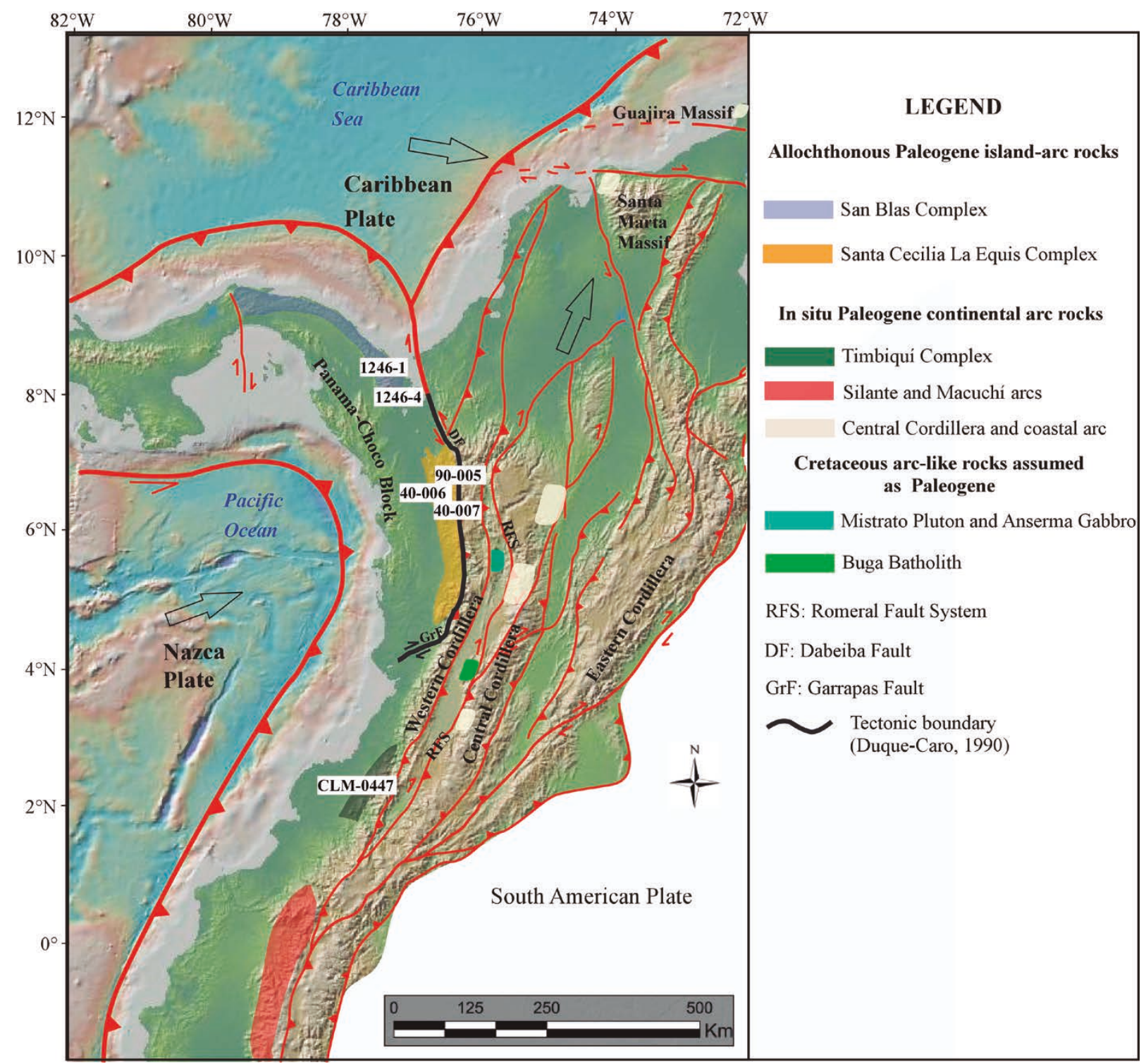

Figure 1. Tectonic setting of the northern Andes showing information not taken into consideration or wrongly interpreted by Grajales et al. (2020) for their paleogeographic and tectonic model: Contemporaneous Paleogene arc-like rocks derived from continental and island arcs, tectonic boundary proposed by Duque-Caro (1990) for the Panama-Choco Block, Cretaceous rocks assumed as Paleogene and included in interpretations, location of samples already published by BarbosaEspitia et al. (2019) (numbers in the map). 
ent ages represent post crystallization cooling to temperatures below $\sim 350^{\circ} \mathrm{C}$ and cannot be considered as crystallization ages. Although Grajales et al. (2020) presented a corrigendum for these inconsistencies, geochemical data from the Anserma Gabbro, Mistrato Pluton and Buga Batholith are still included in the Paleogene magmatism of the CC (Grajales et al., 2020, figures 4 and 5, suppl. mat.) (Figure 1). The Buga Batholith, as well as the Mistrato Pluton were dated as Cretaceous U/Pb zircon ages; (Pardo-Trujillo et al., 2020; Villagómez et al., 2011), whereas the Anserma Gabbro was dated in the same temporal range using whole rock K/Ar ages (Maya, 1992). The wrong assumption of these plutonic bodies as Paleogene in age, which is clearly incorrect, creates serious conflicts in the interpretation of the tectonic setting of the Northern Andes during Cretaceous and Paleogene time. According to several authors, during Cretaceous and Paleogene time a series of tectonic events took place in the paleocontinental margin of NW South America with consequences for arc magmatism and sedimentary basins infill (e.g., Villagómez et al., 2011; Montes et al., 2019; Pardo-Trujillo et al., 2020; Bayona et al., 2021). Furthermore, Grajales et al. (2020) reported six zircon U-Pb ages (samples 1246-1, 1246-4, 40-006-CPC, 90-005-CPC, 40-007-CPC, CLM-0447-P) already published by Barbosa-Espitia et al. (2019) without citation or citing ANH-GRP (2014) (Grajales et al., 2020, tables 1 and 4). Compiled U/Pb ages for the samples X, XX, APO-0056-LG, CLM-0376-R, CDG-0255-P (Grajales et al., 2020, table 4), are not reported in Cardona et al. (2018), or ANH- GRP (2014), which citation is in fact ANH-GRP (2011); therefore, it is unknown where geochronological data of these samples come from. The incorrect assumptions of Grajales et al. (2020) and lack of care with the data compilation brings confusion instead of shedding light on the origin and evolution of the Paleogene arc magmatism in the Northern Andes.

\section{GEOCHEMISTRY AND ITS RELATIONSHIP WITH MIGRATION AND EMPLACEMENT OF INTRUSIVES}

Grajales et al. (2020) used the temporal and apparent compositional similarities of the arc-like rocks of the Panama-Choco Block and Timbiquí Complex (Figure 1) to propose continuation of the Paleogene arc-like magmatism along the entire WC. They argue that all these rocks belong to the Panama-Choco Block, citing Zapata-García and Rodríguez-García (2020). Barbosa-Espitia et al. (2019) suggested that the contemporaneous Paleogene arc-like rocks from the northern WC and southern WC have different origin and cannot be related on the basis of new and preexistent geochemical and isotopic data. Following the simplistic interpretation of Zapata-García and Rodríguez-García (2020), Grajales et al. (2020) proposed that the geochemical differences in arc-like rocks from the Panama-Choco Block and CC are related to subduction of the Farallon plate and basaltic magma emplacement related to tensional fractures. This explanation, however, is inconsistent with the extensive magmatism in the Panama-Choco Block represented by the Paleogene Mandé Batholith, which is a large tholeiitic-calcalkaline pluton emplaced under low- pressure conditions (BarbosaEspitia et al., 2019) and separated from the Cretaceous WC rocks by a tectonic boundary (Duque-Caro, 1990) (Figure 1). The Mandé Batholith is similar to plutonic outcrops in Panama and northern Colombia (Acandí Region), which show geochemical signatures akin to intra oceanic arc settings (e.g., Salazar et al., 1991; Wegner et al., 2011; Montes et al., 2012; Cardona et al., 2018; Sánchez-Celis et al., 2018; Barbosa-Espitia et al., 2019). Moreover, Grajales et al. (2020) used $\mathrm{Sr} / \mathrm{Y}$ vs. MgO diagram to propose emplacement of arc-like rocks within the Panama-Choco Block (northern WC) in a continental border. However, Grajales et al. (2020) did not discuss that the fields in this diagram are a function of the degree of fractional crystallization of minerals within the magma, which in turn depend on pressure. In their diagram, it is evident that fractional crystallization of arc-like rocks from the Panama-Choco Block (northern WC) occurred under lower pressure conditions, given by the decrease of $\mathrm{Sr} / \mathrm{Y}$ with increasing $\mathrm{MgO}$ (Figure 2), which suggest the presence of plagioclase in the magma. This is in stark contrast with the behavior of the southern WC and CC arc-like rocks, which show an increase in $\mathrm{Sr} / \mathrm{Y}$ when $\mathrm{MgO}$ decreases, a feature that indicates the presence of amphibole \pm garnet
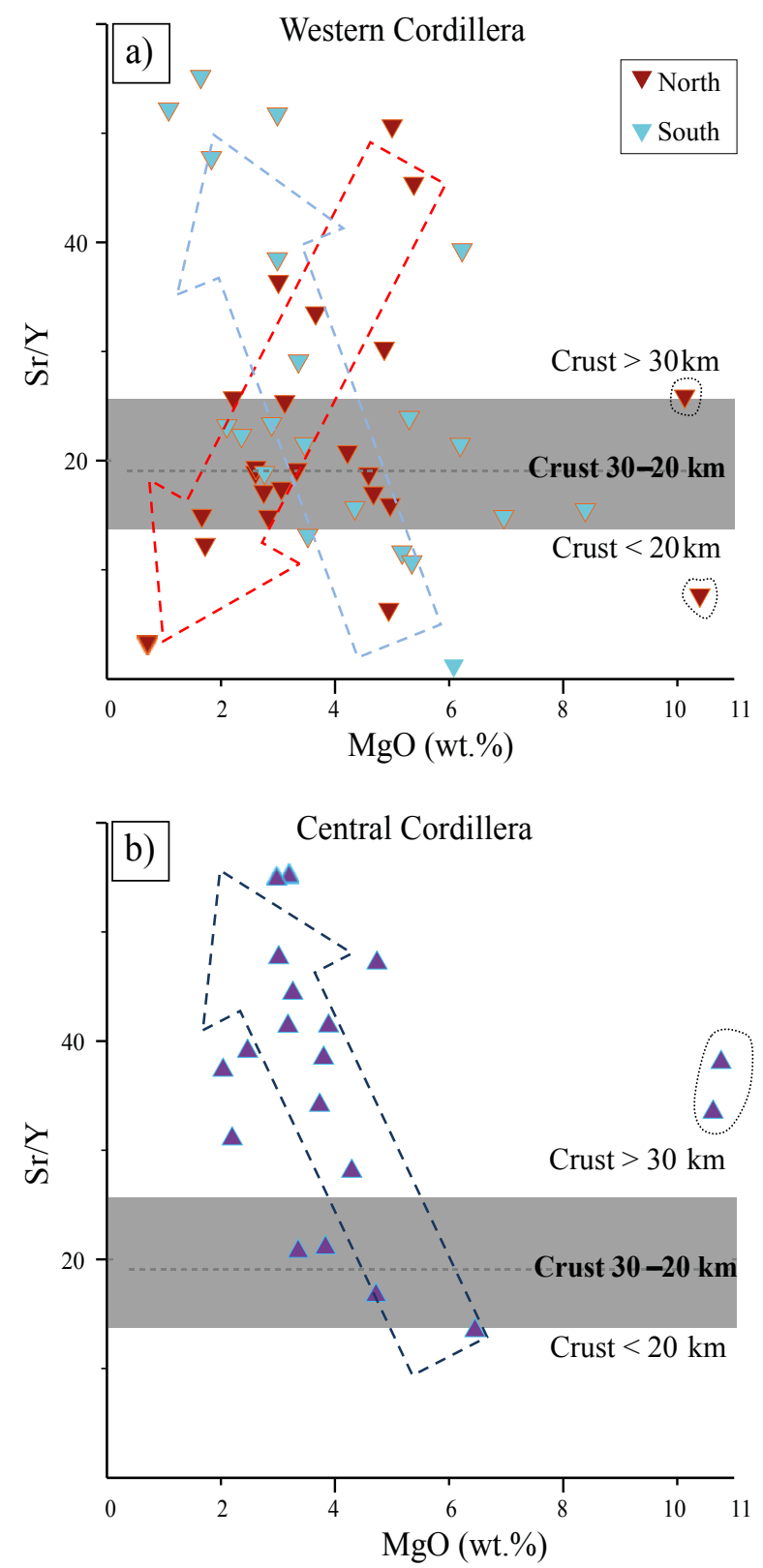

Figure 2. Sr/Y vs. MgO diagram by Grajales et al. (2020) reinterpreted in this comment. Red arrow represents a decrease in $\mathrm{Sr} / \mathrm{Y}$ with differentiation due to the presence of plagioclase in the magma, implying crystallization under lower pressure conditions. Blue arrow represents an increase in $\mathrm{Sr} / \mathrm{Y}$ with differentiation due to the presence of amphibole \pm garnet and plagioclase suppression, implying crystallization under intermediate to high-pressure conditions in a thick crust, characteristic of continental arcs. North Western Cordillera samples are from the Panama-Choco Block. Dotted circles represent outliers. 
and crystallization under intermediate to high pressure conditions (Figure 2). Contrasting Sr/Y behavior between the Panama-Choco Block and the southern segment of the WC arc-like rocks was already noted by Barbosa-Espitia et al. (2019), who used these geochemical differences along with isotopic data and previous provenance studies within contemporaneous units in Ecuador (Vallejo et al., 2009) to propose a continental arc origin for the igneous suites of the southern WC compared to the island arc origin for the Panama-Choco Block. Geochemical evidence clearly suggests contrasting tectonic settings for Paleogene igneous rocks of the Panama-Choco block and southern portions of the WC.

\section{COMPARISON BETWEEN PREVIOUSLY PROPOSED PALEOGEOGRAPHIC AND TECTONIC MODELS FOR THE NORTHERN ANDES AND PANAMA, AND THAT PROPOSED BY GRAJALES ET AL. (2020)}

In addition to the rocks studied by Grajales et al. (2020), the paleogeographic and tectonic settings of the Northern Andes during Paleogene times involve arc-like rocks of the costal arc in northern Colombia (Santa Marta and Guajira massifs); San Blas Complex in Panamá; and Silante and Macuchí arcs in Ecuador (Figure 1). All these rocks have been studied by several authors with different techniques including paleomagnetism, provenance, geochemistry, geochronology and isotopic analyses (e.g., Restrepo and Toussaint, 1990; Estrada, 1995; Chiaradia, 2009; Pindell and Kennan, 2009; Vallejo et al., 2009; Cardona et al., 2011; Bayona et al., 2012; Montes et al., 2012, Boschman et al., 2014; Cardona et al., 2014; Salazar et al., 2016; Wright et al., 2016; Cardona et al., 2018; Montes et al., 2019; Vallejo et al., 2019, 2020). As a result of these works, a robust model was proposed and refined in recent studies (Cardona et al., 2018; Barbosa-Espitia et al., 2019) (Figure $3 \mathrm{a}$ and $3 \mathrm{~b}$ ). This model suggests that the Paleogene arc-like rocks in the region were generated by subduction of the Caribbean and Farallon plates. According to this model, the N-NW movement of the Caribbean plate resulted in subduction beneath the northern paleocontinental margin of Colombia generating the arc-like rocks in the Central Cordillera, as well as Santa Marta and Guajira massifs (Cardona et al., 2011; Bayona et al., 2012; Cardona et al.,2014, Salazar et al., 2016; Bustamante et al., 2017; Cardona et al.,2018). On the other hand, the subduction of the Farallon plate generated the arc-like rocks of southern Colombia and Ecuador, as well as Panamá, including its accreted sector in northern Colombia (Cardona et al., 2018; BarbosaEspitia et al., 2019) (Figure 3a and b). In contrast, Grajales et al. (2020) place their data into an in-situ model, without a discussion on how the data support this model or why they discarded the Caribbean and Farallon plates double-subduction model. The Grajales et al. (2020) model implies that the southern sector of the Panama-Choco Block was already accreted to the continental margin during Early Paleogene and that the oblique subduction of the Farallon plate would have generated simultaneous magmatism in the CC and WC (Figure 3c and d). However, this interpretation contradicts thermochronological, structural, and paleomagnetic data from Colombia and Panama suggesting that the Panama-Choco Block was accreted during the Neogene to north western Colombia (MacDonald, 1980; Suter et al., 2008; Farris et al., 2011; Barat et al., 2014; Piedrahita et al., 2017; León et al., 2018). This model neither can explain the Paleogene magmatism in the Santa Marta and Guajira massifs (Cardona et al., 2011, 2014; Salazar et al., 2016), high-pressure metamorphic rocks associated to suture zones reported in western Colombia (Bustamante and Bustamante, 2019; Avellaneda-Jiménez et al., 2020; Bustamante et al., 2020) and faults that bound the Panama-Choco block and southern sector of the
WC (Figure 3c). All these data and studies must be considered and fully discussed to construct an integrative-alternative in situ paleogeographic model. Without the consideration of these data, the in situ model proposed by Grajales et al. (2020) lacks support and reliability.

The lack of care with the compilation of geochemical and geochronological data and poor discussion of geochemical data presented by Grajales et al. (2020), along with the extensive and diverse set of data presented during the last four decades indicate that a double subduction system controlled by the convergence of the Caribbean and Farallon plates beneath the north Andean block during Paleogene, is the more plausible explanation for the contemporaneous arc-like magmatism, currently located in disparate segments of the northwestern Andes.

\section{CONCLUSIONS}

We reviewed the data presented by Grajales et al (2020) and found serious inaccuracies in the compilation and interpretation of the data. In order to propose a new Paleogene paleogeographic and tectonic model for the complex geologic history of the Northern Andes, all published data must be evaluated, and discussed considering the limitations of the data. If the data is not accurately interpretated, then the subsequent models and conclusions will be erroneous. New ideas and interpretations to understand the complex geology of the Northern Andes must be based on consideration and citation of previous works, and use of extant and new data. Models not supported by data bring confusion to relevant aspects of the geologic history of Colombia such as the timing of ore deposit formation, closure time of fore arc basins in western Colombia, and post Paleogene tectonic events such as the collision of the Panama-Choco Block.

\section{ACKNOWLEDGEMENTS}

We would like to thank the Agencia Nacional de Hidrocarburos $(\mathrm{ANH})$, project: Tectonostratigraphic characterization of the Colombian Pacific Basins, for the financial support. Staff of the Instituto de Investigaciones en Estratigrafia (IIES) at the Universidad de Caldas and the Consorcio Pacifico Colombiano (CPC) are acknowledgement for their always timely support in the field and office work.

\section{REFERENCES}

ANH-GRP (Agencia Nacional de Hidrocarburos, Geología Regional y Prospección), 2011, Cartografía geológica a escala 1:100.000 de las planchas 340, 362, 385 y 409 localizadas en la Cuenca de Tumaco, así como el inherente levantamiento de columnas estratigráficas y muestreo litológico para los análisis petrográficos, bioestratigráficos, geoquímicos, petrofísicos y radiométricos: Agencia Nacional de Hidrocarburos, technical report, 207 pp <http://recordcenter.sgc.gov.co/B14/23008010024581/documento/ pdf/2105245811101000.pdf>

ANH-GRP (Agencia Nacional de Hidrocarburos, Geología Regional y Prospección), 2014, Cartografía geológica a escala 1:100.000 de las planchas 340, 362, 385 y 409 localizadas en la Cuenca de Tumaco, así como el inherente levantamiento de columnas estratigráficas y muestreo litológico para los análisis petrográficos, bioestratigráficos, geoquímicos, petrofísicos y radiométricos: Bogotá, Colombia, Agencia Nacional de Hidrocarburos, Publicación Especial, 207 pp. <http://recordcenter.sgc. gov.co/B14/23008010024581/documento/pdf/2105245811101000.pdf>

ANH-UCaldas (Agencia Nacional de Hidrocarburos, Universidad de Caldas, ) 2011, Estudio integrado de los núcleos y registros obtenidos de los pozos someros tipo "slim holes" en la cuenca del Sinu: Agencia Nacional de Hidrocarburos, technical report, $71 \mathrm{pp}$. 


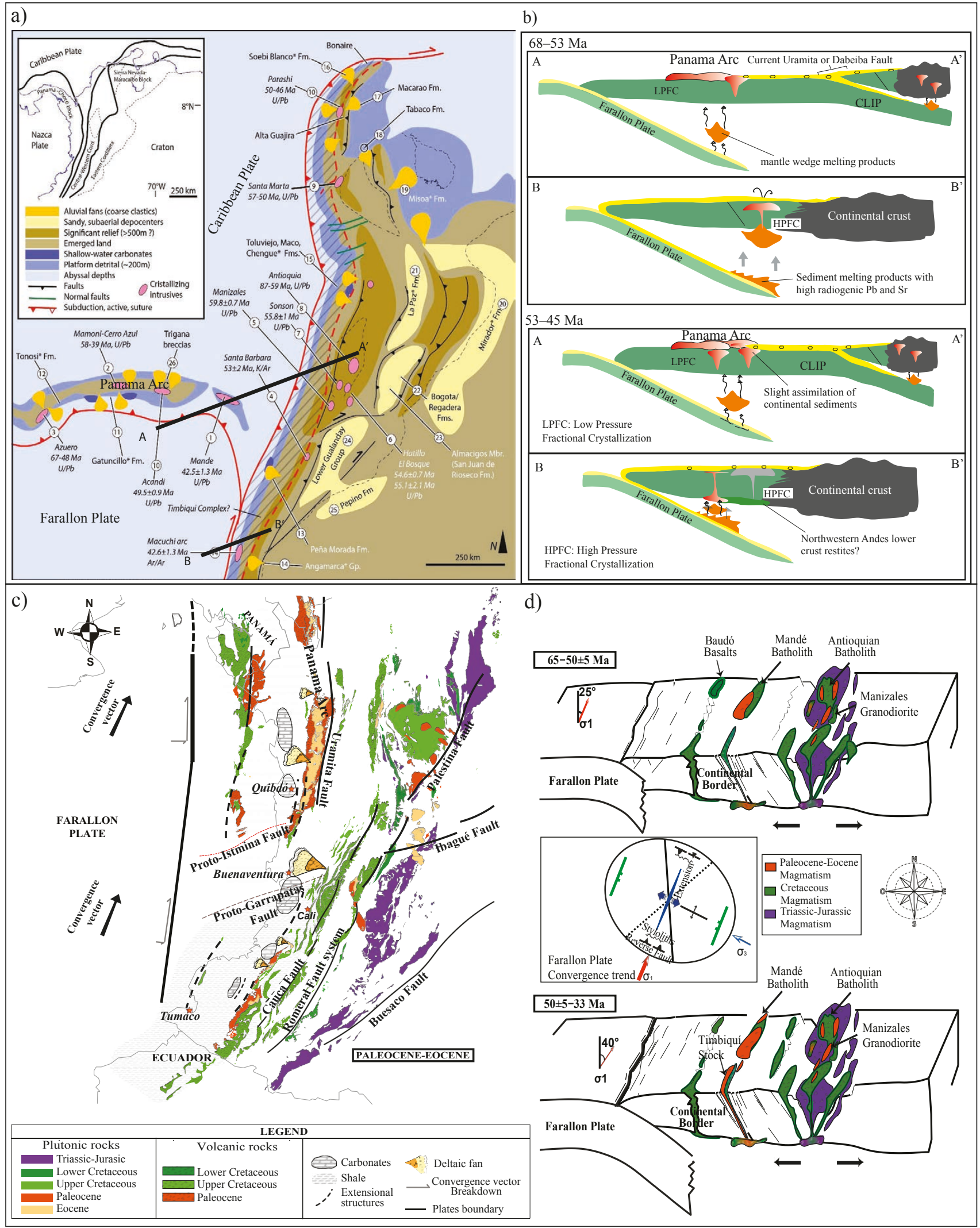

Figure 3. Comparison between double-subduction and single-subduction models for the northern Andes and Panama. a) Previously proposed double-subduction paleogeographic model [after Cardona et al. (2018)] and b) tectonic model [after Barbosa-Espitia et al. (2019)]. c) Single- subduction paleogeographic and d) tectonic model proposed by Grajales et al. (2020). The tectonic model proposed by Grajales et al. (2020) do not take into consideration geographic separation between the Mande Batholith and the Timbiquí Stock. These plutons are separated by hundreds of kilometers and presumably fault bounded, as Grajales et al. (2020) correctly show in the paleogeographic model on c. 
Avellaneda-Jiménez, D.S., Cardona, A., Valencia, V., León, S., Blanco-Quintero, I.F., 2020, Metamorphic gradient modification in the Early Cretaceous Northern Andes subduction zone: A record from thermally overprinted high-pressure rocks: Geoscience Frontiers, https://doi.org/10.1016/j. gsf.2020.09.019

Barat, F., Mercier de Lépinay, B., Sosson, M., Müller, C., Baumgartner, P.O., Baumgartner- Mora, C., 2014, Transition from the Farallon Plate subduction to the collision between South and Central America: Geological evolution of the Panama Isthmus: Tectonophysics, 622, 145-167, https:// doi.org/10.1016/j.tecto.2014.03.008

Barbosa-Espitia, Á.A., Kamenov, G.D., Foster, D.A., Restrepo-Moreno, S.A., Pardo-Trujillo, A., 2019, Contemporaneous Paleogene arc-magmatism within continental and accreted oceanic arc complexes in the northwestern Andes and Panama: Lithos, 348-349, 105185, https://doi.org/10.1016/j. lithos.2019.105185

Bayona, G., Cardona, A., Jaramillo, C., Mora, A., Montes, C., Valencia, V., Ayala, C., Montenegro, O., Ibañez-Mejia, M., 2012, Early Paleogene magmatism in the northern Andes: Insights on the effects of Oceanic Plateau-continent convergence: Earth Planetary Science Letters, 331-332(0), 97-111, https:// doi.org/10.1016/j.epsl.2012.03.015

Bayona, G., Baquero, M., Ramírez, C., Tabares, M., Salazar, A.M., Nova, G., Duarte, E., Pardo, A., Plata, A., Jaramillo, C., Rodríguez, G., Caballero, V., Cardona, A., Montes, C., Marulanda, S.G., Cárdenas-Rozo, A.L., 2021, Unravelling the widening of the earliest Andean northern orogen: Maastrichtian to early Eocene intra-basinal deformation in the northern Eastern Cordillera of Colombia: Basin Research, 33(1), 809-845, https:// doi.org/10.1111/bre.12496

Boschman, L.M., van Hinsbergen, D.J.J., Torsvik, T.H., Spakman, W., Pindell, J.L., 2014, Kinematic reconstruction of the Caribbean region since the Early Jurassic: Earth-Science Reviews, 138, 102-136, https://doi.org/10.1016/j. earscirev.2014.08.007

Bustamante, A., Bustamante, C., Cardona, A., Juliani, C., Pereira da Silva, S., 2020, Jambaló blueschist and greenschist protoliths in the Central Cordillera of the Colombian Andes and their tectonic implications for Late Cretaceous Caribbean-South American interactions: Journal of South American Earth Sciences, 102977, https://doi.org/10.1016/j. jsames.2020.102977

Bustamante, C., Bustamante, A., 2019, Two Cretaceous subduction events in the Central Cordillera: Insights from the high P-low T metamorphism, in Gómez, J., Pinilla-Pachon, A.O., (eds.), The Geology of Colombia, 2: Servicio Geológico Colombiano, Publicaciones Geológicas Especiales, 37, 485-498.

Bustamante, C., Cardona, A., Archanjo, C.J., Bayona, G., Lara, M., Valencia, V., 2017, Geochemistry and isotopic signatures of Paleogene plutonic and detrital rocks of the Northern Andes of Colombia: A record of postcollisional arc magmatism: Lithos, 277, 199-209, https://doi.org/10.1016/j. lithos.2016.11.025

Cardona, A., Valencia, V., Bayona, G., Duque, J., Ducea, M., Gehrels, G., Jaramillo, C., Montes, C., Ojeda, G., Ruiz, J., 2011, Early-subductionrelated orogeny in the northern Andes: Turonian to Eocene magmatic and provenance record in the Santa Marta Massif and Rancheria Basin, northern Colombia: Terra Nova, 23(1), 26-34.

Cardona, A., Weber, M., Valencia, V., Bustamante, C., Montes, C., Cordani, U., Muñoz, C., 2014, Geochronology and geochemistry of the Parashi granitoid, NE Colombia: Tectonic implication of short-lived Early Eocene plutonism along the SE Caribbean margin: Journal of South American Earth Sciences, 50, 75-92.

Cardona, A., León, S., Jaramillo, J.S., Montes, C., Valencia, V., Vanegas, J., Bustamante, C., Echeverri, S., 2018, The Paleogene arcs of the northern Andes of Colombia and Panama: Insights on plate kinematic implications from new and existing geochemical, geochronological and isotopic data: Tectonophysics, 749, 88-103, https://doi.org/10.1016/j.tecto.2018.10.032

Chiaradia, M., 2009, Adakite-like magmas from fractional crystallization and melting- assimilation of mafic lower crust (Eocene Macuchi arc, Western Cordillera, Ecuador): Chemical Geology, 265(3-4), 468-487, https://doi. org/10.1016/j.chemgeo.2009.05.014

Duque-Caro, H., 1990, The Choco Block in the northwestern corner of South America: Structural, tectonostratigraphic, and paleogeographic implications: Journal of South American Earth Sciences, 3(1), 71-84,
https://doi.org/10.1016/0895-9811(90)90019-W

Estrada, J.J., 1995, Paleomagnetism and accretion events in Northern Andes: Binghamton, U.S.A., University State of New York, Ph.D. Thesis, 172 pp.

Farris, D.W., Jaramillo, C., Bayona, G., Restrepo-Moreno, S.A., Montes, C., Cardona, A., Mora, A., Speakman, R. J., Glascock, M. D., Valencia, V., 2011, Fracturing of the Panamanian Isthmus during initial collision with South America: Geology, 39(11), 1007-1010.

Grajales, J.A., Nieto-Samaniego, A.F., Barrero Lozano, D., Osorio, J.A., Cuellar, M.A., 2020, Emplazamiento del magmatismo Paleoceno-Eoceno bajo un régimen transtensional y su evolución a un equilibrio dinámico en el borde occidental de Colombia: Revista Mexicana de Ciencias Geológicas, 37(3), 250-268, http://dx.doi.org/10.22201/cgeo.20072902e.2020.3.1570

León, S., Cardona, A., Parra, M., Sobel, E.R., Jaramillo, J.S., Glodny, J., Valencia, V.A., Chew, D., Montes, C., Posada, G., Monsalve, G., Pardo-Trujillo, A., 2018, Transition From Collisional to Subduction-Related Regimes: An Example From Neogene Panama- Nazca-South America Interactions: Tectonics, 37(1), 119-139, https://doi.org/10.1002/2017TC004785

MacDonald, W., 1980, Anomalous paleomagnetic directions in the late Tertiary andesitic, intrusions of the Cauca Depression, Colombian Andes: Tectonophysics, 68(3-4), 339-348.

Maya, M., 1992, Catálogo de las dataciones isotópicas en Colombia: Boletín Geológico de Ingeominas, 31(1-3), 127-187.

Montes, C., Bayona, G., Cardona, A., Buchs, D. M., Silva, C., Morón, S., Hoyos, N., Ramírez, D., Jaramillo, C., Valencia, V., 2012, Arc-continent collision and orocline formation: Closing of the Central American seaway: Journal of Geophysical Research: Solid Earth, 117(B4), Article B4.

Montes, C., Rodriguez-Corcho, A.F., Bayona, G., Hoyos, N., Zapata, S., Cardona, A., 2019, Continental margin response to multiple arc-continent collisions: The northern Andes-Caribbean margin: Earth-Science Reviews, 198, 102903, https://doi.org/10.1016/j.earscirev.2019.102903

Pardo-Trujillo, A., Cardona, A., Giraldo, A.S., León, S., Vallejo, D.F., TrejosTamayo, R., Plata, A., Ceballos, J., Echeverri, S., Barbosa-Espitia, A., Slattery, J., Salazar-Ríos, A., Botello, G.E., Celis, S. A., Osorio-Granada, E., Giraldo-Villegas, C.A., 2020, Sedimentary record of the CretaceousPaleocene arc-continent collision in the northwestern Colombian Andes: Insights from stratigraphic and provenance constraints: Sedimentary Geology, 401, 105627, https://doi.org/10.1016/j.sedgeo.2020.105627

Piedrahita, V.A., Bernet, M., Chadima, M., Sierra, G.M., Marín-Cerón, M.I., Toro, G.E., 2017, Detrital zircon fission-track thermochronology and magnetic fabric of the Amagá Formation (Colombia): Intracontinental deformation and exhumation events in the northwestern Andes: Sedimentary Geology, 356, 26-42, https://doi.org/10.1016/j.sedgeo.2017.05.003

Pindell, J.L., Kennan, L., 2009, Tectonic evolution of the Gulf of Mexico, Caribbean and northern South America in the mantle reference frame: An update: Geological Society, London, Special Publications, 328(1), 1-55, https://doi.org/10.1144/SP328.1

Restrepo, J.J., Toussaint, J.F., 1990, Cenozoic arc magmatism of northwestern Colombia, in Kay, S.M., Rapela, C.W. (eds.), Plutonism from Antarctica to Alaska: The geological Society of America, 241, 205-212.

Salazar, C.A., Bustamante, C., Archanjo, C.J., 2016, Magnetic fabric (AMS, AAR) of the Santa Marta batholith (northern Colombia) and the shear deformation along the Caribbean Plate margin: Journal of South American Earth Sciences, 70, 55-68, https://doi.org/10.1016/j.jsames.2016.04.011

Salazar, G., James, M., Tistl, M., 1991, El Complejo Santa Cecilia - La Equis: Evolución y acreción de un arco magmático en el norte de la Cordillera Occidental, Colombia, in Memorias del simposio de magmatismo andino y su marco tectónico: Manizales, Colombia, Instituto Nacional de Investigaciones Geológico Mineras, 142-160.

Sánchez-Celis, D., Frantz, J.C., Charão-Marques, J., Barrera-Cortés, M., 2018, Petrología del Batolito de Acandí y cuerpos asociados, Unguía-Chocó, Colombia: Boletín de Geología, 40(1), 63-81, https://doi.org/10.18273/ revbol.v40n1-2018004

Suter, F., Sartori, M., Neuwerth, R., Gorin, G., 2008, Structural imprints at the front of the Chocó-Panamá indenter: Field data from the North Cauca Valley Basin, Central Colombia: Tectonophysics, 460(1-4), 134-157.

Vallejo, C., Winkler, W., Spikings, R.A., Luzieux, L., Heller, F., Bussy, F., 2009, Mode and timing of terrane accretion in the forearc of the Andes in Ecuador: Geological Society of America Memoirs, 204, 197-216.

Vallejo, C., Spikings, R.A., Horton, B.K., Luzieux, L., Romero, C., Winkler, 
W., Thomsen, T.B., 2019, Late Cretaceous to Miocene stratigraphy and provenance of the coastal forearc and Western Cordillera of Ecuador: Evidence for accretion of a single oceanic plateau fragment, in Horton, B.K., Folguera, A., (eds.), Andean Tectonics: Elsevier, 209-236.

Vallejo, C., Almagor, S., Romero, C., Herrera, J.L., Escobar, V., Spikings, R.A., Winkler, W., Vermeesch, P., 2020, Sedimentology, Provenance and Radiometric Dating of the Silante Formation: Implications for the Cenozoic Evolution of the Western Andes of Ecuador: Minerals, 10(10), 929, https://doi.org/10.3390/min10100929

Villagómez, D., Spikings, R., 2013, Thermochronology and tectonics of the Central and Western Cordilleras of Colombia: Early Cretaceous-Tertiary evolution of the northern Andes: Lithos, 160, 228-249.

Villagómez, D., Spikings, R., Magna, T., Kammer, A., Winkler, W., Beltrán, A., 2011, Geochronology, geochemistry and tectonic evolution of the Western and Central cordilleras of Colombia: Lithos, 125(3-4), 875-896, https:// doi.org/10.1016/j.lithos.2011.05.003

Wegner, W., Wörner, G., Harmon, R.S., Jicha, B.R., 2011, Magmatic history and evolution of the Central American Land Bridge in Panama since Cretaceous times: Geological Society of America Bulletin, 123(3-4), 703724, https://doi.org/10.1130/b30109.1
Wright, N.M., Seton, M., Williams, S.E., Müller, R.D., 2016, The Late Cretaceous to recent tectonic history of the Pacific Ocean basin: Earth-Science Reviews, 154, 138-173, https://doi.org/10.1016/j.earscirev.2015.11.015

Zapata-García, G., Rodríguez-García, G., 2020, New Contributions to Knowledge about the Chocó-Panamá Arc in Colombia, Including a New Segment South of Colombia in Gómez, J., Mateus-Zabala, D. (eds.), The Geology of Colombia, 3: Servicio Geológico Colombiano, Publicaciones Geológicas Especiales 37, 417-450, https://doi.org/10.32685/pub.esp.37.2019.14

Comment received: february 7, 2021

Comment accepted: may 6, 2021 